\title{
The Role of Geographical Landscape Studies for Sustainable Territorial Planning
}

\author{
Iván Franch-Pardo ${ }^{1, *}$ (D), Brian M. Napoletano ${ }^{2, *}$ (D), Gerardo Bocco ${ }^{2}$, Sara Barrasa ${ }^{2}$ (1) and \\ Luis Cancer-Pomar ${ }^{3}$ \\ 1 Escuela Nacional de Estudios Superiores Morelia, Universidad Nacional Autónoma de México, \\ Campus Morelia, 58190 Morelia, Michoacán, Mexico \\ 2 Centro de Investigaciones en Geografía Ambiental, Universidad Nacional Autónoma de México, \\ Campus Morelia, 58190 Morelia, Michoacán, Mexico; gbocco@ciga.unam.mx (G.B.); \\ sbarrasa@ciga.unam.mx (S.B.) \\ 3 Department of Physical Geography and CEACTierra, University of Jaen, 23071 Jaen, Spain, lcancer@ujaen.es \\ * Correspondence: ifranch@enesmorelia.unam.mx (I.F.-P.); brian@ciga.unam.mx (B.M.N.)
}

Received: 12 September 2017; Accepted: 7 November 2017; Published: 17 November 2017

\begin{abstract}
One of the primary objectives of physical geography is to determine how natural phenomena produce specific territorial patterns. Therefore, physical geography offers substantial scientific input into territorial planning for sustainability. A key area where physical geography can contribute to land management is in the delimitation of landscape units. Such units are fundamental to formal socio-economic zoning and management in territorial planning. However, numerous methodologies-based on widely varying criteria - exist to delineate and map landscapes. We have selected five consolidated methodologies with current applications for mapping the landscape to analyse the different role of physical geography in each: (1) geomorphological landscape maps based on landforms; (2) geosystemic landscape maps; (3) Landscape Character Assessment; (4) landscape studies based on visual landscape units; (5) landscape image-pair test. We maintain that none of these methodologies are universally applicable, but that each contributes important insights into landscape analysis for land management within particular biogeophysical and social contexts. This work is intended to demonstrate that physical geography is ubiquitous in contemporary landscape studies intended to facilitate sustainable territorial planning, but that the role it plays varies substantially with the criteria prioritized.
\end{abstract}

Keywords: environmental geography; landscape delimitation and mapping; geomorphology; geosystem-territory-landscape; viewshed; Landscape Character Assessment; image-pair test; territorial planning

\section{Introduction}

Sustainability is primarily concerned with environmental change, but is increasingly recognised as an inherently political concept, both in its formulation and implications [1]. In the sense of sustainable human-development, it is based on three overlapping concerns (see Figure 1): (1) environmental change and its anthropogenic drivers and adaptation thereto; (2) poverty and other forms of economic inequality [2,3]; and (3) injustice, power disparities, and the gap between really existing democracy and its popular definition, particularly with respect to management of and access to material resources $[4,5]$. This conception of sustainability as an integrating concept, in turn, has drawn attention to the need to address the ontological and epistemological disciplinary gaps between the social and natural sciences to adequately understand the social production and consumption of scientific knowledge and the complex relationships between humans, social systems, and their biogeophysical reality $[1,6]$. 


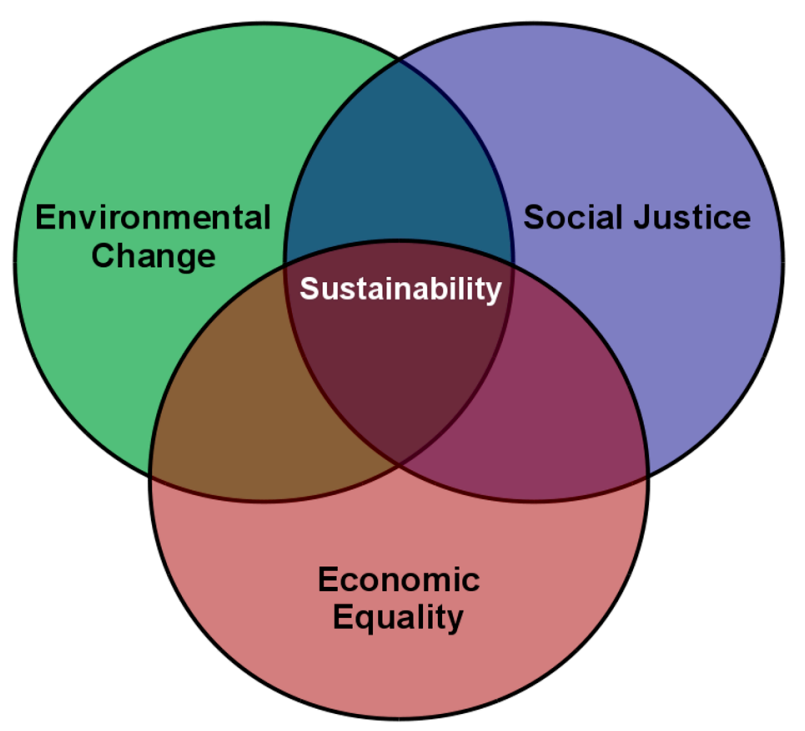

Figure 1. Sustainability at the intersection of efforts to address environmental change, social justice, and economic equality.

Recent scholarship regarding the epistemology of geography contends that it plays an important role in sustainability science owing to its inclusive approach to human and physical factors when dealing with territorial studies [2] and the landscape as an integrating concept [7]. In the words of Castree et al. (2009) [8], this is one of the few disciplines dedicated to overcoming the disciplinary division between natural (physical) and social (human) science. Leng (2017) [9] goes further, stating that no other field is more focused on studying Earth's human occupation than geography, with a "full spectrum" perspective to explain the relation between environment and society [10,11].

Sauer (1925) [12] justifies the existence of geography as an independent science as per its profound knowledge of the different and eclectic shapes and processes on the Earth's surface. Therefore, these authors agree that the complexity of the actual reality of the environment-society dialectic (sensu Schnaiberg and Gould, 1994) [13] must be understood in the context of geography's integrative approach. Geography is not a general science of the Earth, but it defines its characteristics and general processes, or integrates them into a spatial context from other disciplines. This preference for the concise knowledge of the general science of the Earth is consistent with geography's tradition [11].

The characterization of geography as an integrative approach in contemporary scientific literature should be understood as an important counterpoint to other schools of thought that advocate furthering the dualistic split between science and philosophy, and humanity and nature [14]. This integrated approach in geography also provides an important counterweight to, on the one hand, deterministic ideological positions that purport to reduce complex social systems to a handful of essential environmental factors (e.g., Diamond, 1999) [15] or biological determinants of human "nature" (e.g., Wilson, 2002) [16], and on the other hand, various forms of radical constructionism-as-philosophical-critique that deny the existence of an objective reality and therefore any form of non-human nature apart from a social concept of it [17], and social monism that describe non-human nature as produced by society [18].

Our approach to the integration of human and physical geography is therefore consistent with positions that mandate the integration of the natural and social sciences, particularly with regards to social and ecological sustainability $[14,19,20]$. In terms of more pragmatic concerns with territorial management and planning studies for sustainability, this position is considered to be essential [21-23].

The purpose of this review is to highlight the different ways in which physical and human geography are integrated in landscape studies for sustainable territorial management-i.e., land-use planning and its implementation-by considering the role of physical geography (PG) in five 
widely used geographical approaches to landscape mapping. The work reviewed here is focused on the dimensions of physical geography that deal explicitly with the landscape, which presents an optimal element in territorial management with regards to sustainability because of its synthetic character and integration of both biogeophysical and human features. The remainder of this article is organized as follows: first, a brief reflection about the position of PG as an academic discipline and a theme in environmental science; secondly, territorial planning is conceptualized, and within this, the geographical landscape is evaluated. Third, we describe some of the diverse methodologies used to map landscapes, focusing on guidelines, procedures, and applications. Because we are particularly interested in the diverse role of PG in landscape studies, we have selected five methodologies based on highly consolidated geographical approaches that are sustained by deep and highly consolidated epistemological roots in the geographic tradition, which are contemporaneously practised in different territorial contexts at present and manifest different degrees of imbrication with PG. These five methodologies are as follows:

1. Geomorphic landscape maps based on landforms

2. Geosystemic landscape maps

3. Landscape Character Assessment

4. Landscape studies based on visual landscape units

5. Landscape assessment with image pairs

Fourth, these methodologies are compared in terms of their suitability for different proposed objectives and their contributions to sustainability.

\subsection{Environmental Geography and Sustainable Territorial Planning}

In contrast to the dualistic positions mentioned previously, we maintain that a more dialectical position is needed in geography, where both human and non-human factors are considered as a dialectical unity in order to explain certain environmental phenomena-a position that we consider the essence of geography, now called environmental geography [8,9,24-27].

To deal with the growing number of problems that it must address (land change, climate change, contamination, resource extraction, etc.), modern environmental science is based on the postulates traditionally promulgated by geography $[9,28]$. Due to this situation, the environmental term has been added to geography, and environmental geography is considered an emerging science [26,27,29]. It studies environmental issues from a geographical perspective, which entails using knowledge and concepts typical of this discipline. Its contribution to environmental science includes integrated approaches which explain space, size, and distribution of land cover and use, and the implications of the fact that landscapes result from complex interactions between society and nature, or coupled natural-human systems [6]. Extensive research on increasingly complex environmental issues requires from geography an interdisciplinary approach where research methods from fields as diverse geochemistry and environmental economics are used. In short, the scope of environmental geography exceeds that of geography in its traditional orientation [8].

Insofar as the objective of geography is to understand how phenomena are organized in space, one of PG's more important objectives vis-à-vis sustainability is to help explain how natural phenomena contribute to specific territorial patterns [30], interrelating physical and human environmental components. PG is more than a compilation of several topics from other sciences; it integrates information into models of human and spatial interaction essential to each one of its supporting sciences [31-35]. The combined action of energy and matter inputs in the biosphere, from the atmosphere and the land, respectively, establishes the initial quality of the environment that serves as the material basis for human society. Therefore, an understanding of PG is essential to human survival on the Earth [31].

In addition to the study of spatial patterns of climate, relief, and hydrology, PG analyses the interrelation between these phenomena and human activities, which some authors have denominated 
as the human-land tradition in the discipline [11]. This approach has gained increasing relevance due to the sustained impact of anthropogenic activity on landscapes and ecosystems therein. For this reason, the integrative approach of geography requires human geographers to engage with the science of physical geography due to the relevance of physical features of the land in shaping social relations. In the same way, physical geographers need to understand the social power relations and human practices that shape biophysical systems [14]. Its main precept is not to rely on explanations based exclusively on human geography or PG, as landscapes are as much the product of unequal power relations, histories of colonialism, and racial and gender disparities as they are of land forms, hydrology, ecology, and climate change [14].

As in human geography, PG has two working lines: on one hand, the scientific business of geographical science, and on the other hand, active participation in integrated paradigms related to sustainability (global change, regional implications, biology biodiversity conservation, land use planning from landscape examination) [30]. As indicated above, we focus here on the aspects of physical geography concerned with landscape mapping, and examine their roles in the delineation of landscape units for territorial planning.

\subsection{Sustainable Territorial Planning and the Geographic Landscape}

According to Cataldo and Rinaldi (2010) [36], the science of territorial planning concerns the process of managing and regulating the activities involved in territorial transformations, and it aims to enable an efficient, self-sufficient, and coordinated relation between human society and the environment. This perspective is well illustrated by Gómez-Orea and Gómez-Villarino (2013) [23]. Relying on geographical determinism, they use the postulates of general systems theory [37] to explain the configuration of territory. The territorial system is defined as an "unavoidable social construction that represents a society's development style" [23] (p. 29), that originates in the beginnings of human settlement. The following is identified in the territorial system:

- the territorial structure, based on integrating components (the physical environment, the population, its productive activities, the population centres, the relational channels, institutions, and the legal framework that establishes the rules);

- the function, established by the relations of the system with the external (territorial levels) and the internal relations (the relation with the physical environment, the settlement model) by flows circulating through the relational channels making a functional system;

This is visually expressed in the image of the system perceived by the population-in other words, the landscape.

The physical aspect of territorial planning is based on PG. In order to make appropriate decisions on territorial issues, the relationships of influential physical and geographic criteria to anthropogenic activities need to be considered. To obtain a harmonious and functional territorial system, the relation between the activities must be analysed, and then an objective for territorial planning that includes the relational channels between activities must be visualised. Finally, given that the objective of territorial planning is to make decisions, the resulting product is a combination of rules and procedures used to define future actions.

Following Gómez-Orea's (2013) [23] argument about the territorial system, both its structure and its behaviour results in the landscape. The landscape, from a geographical point of view, means a combination of elements where all the variables that have an influence on the territory are condensed [38,39]. As Zoido-Naranjo confirms (2005) [40], this involves the location and arrangement of the elements and uses of the territory, as well as the structures or systems of what they are made of. This is useful in territorial assessment, since the favourable and unfavourable uses of the geographical space are included and represented. At the same time, its shapes can be understood and explained, which is essential in order to consciously arrange it. 
To prevent physical geography from being subordinated to the natural sciences [41], we maintain that such a post-postivistic perspective on territorial planning needs to be counter-balanced by aspects of human geography, including a more dialectical and reflexive perspective on the political nature of scientific inquiry and how it is used by different social interests [42]; attention to the social mode and relations of production (historical materialism) [43], their influences on society's metabolism (or aforementioned flows through relational channels) of biogeophysical resources [44], and the spatial patterns, or "geographic rifts", that result [45]; and the importance of social power dynamics and disparities at interpersonal, institutional, and structural levels in influencing the configuration of the landscape [46]. Here, an epistemological basis in critical realism that prioritizes explanatory power over conceptual elegance would be more useful than one in post-positivism [20,47], as would a more inclusive and democratic approach to geography that seeks to support democratic public engagement in decision-making rather than technocratic governance [48].

Such a holistic synthesis would improve the role of territorial analysis, based on landscape elements, in sustainable territorial management. This is particularly relevant to the valuation of the landscape by the people who perceive it, particularly those for whom the land is the space in which they live and work.

We acknowledge the existence of asymmetry between cultural and physical factors in integrated territorial studies [8]; the interconnection is very different in world geography, where there are different grades and types of interactions [8].

The disparity of methods in landscape planning is also related to the asymmetry mentioned by [8]. This asymmetry is due to the geographic reality where the methodology is applied; it depends on the executor's epistemological criterion, the specific purpose of the studies carried out, and underlying ideological and political bias [49]. One of our intentions is to elucidate these kinds of reflections.

The issue of the methodology and its criteria depend first on the definition of the geographic landscape. Landscape is a versatile concept since its meaning changes depending on the context and academic discipline in which it is employed. Designers, architects, painters, historians, ecologists, and geographers each use the landscape as a technical term in their own field, and they define it according to their scientific perspective.

The concept of landscape has been debated more intensely in other languages, such as French and Spanish, than it has in English [50]. In Spanish, for instance, the definition is rephrased in every new edition of the Royal Spanish Academy, RAE (as per initials in Spanish of Real Academia Española) [51]. In its latest edition, the 23rd (2014), landscape is defined as "part of a territory that can be observed from a certain place". In the two previous editions, 1992 and 2001, it was defined as "area that can be seen from a place", and in 1984 (its 20th edition), it was "painting or drawing", "piece of land that can be seen from a place, considering its artistic aspect". On one hand, it is remarkable that in 30 years the term has been modified three times, and on the other hand, the mutation on the concept from a pictorial to a geographic perspective, with the use of terms like territory.

In geography, landscape has a variety of distinctly different meanings. These range from highly deterministic conceptual opinions about physical-geographic landscape to strongly humanist expressions, where the physical evidence of the people who live and lived there is studied [52], as well as the expression of the historical attempt to bring together visual perception and the material world [53], or the sensitive, aesthetic, and experiential perception in the humanist landscape [54].

The idea of landscape with respect to planning, however, cannot be understood without some consideration of the physical factors affecting a geographic space. Therefore, in this work we would like to open a window of observation on the role of PG in different landscape studies. We consider that the geographic landscape is presently a useful means by which to consider the differing role of PG in projects designed to support territorial management. In this way, we consider PG as the conceptual reference that distinguishes certain cartographic procedures from others.

In other words, in geography, the geographic landscape can act as a metric unit, working unit, and application unit. It is the unit where physical, economic, and cultural features coincide, 
and where they can be studied and visualised in unison; where they are coordinated, united, and integrated. The phenomena that make up an area are not simply assorted but are associated, or interdependent. To discover this spatial "connection of phenomena and their order" is a scientific task of geography $[13,55,56]$.

Currently, the scientific community, public administrations, and the public understand the landscape as an environmental element and resource, similar to other environmental and natural resources (water, vegetation, etc.). This resource consideration may be presented from two perspectives [57]: (1) as an environmental resource itself (natural and/or cultural) in need of preservation; or (2) as a resource that decisively influences the ability to develop certain activities or the assignation of certain uses in the territory. Insofar as the state must at least be seen to act as an arbiter of development and environmental quality to preserve its legitimacy [58], the designation of the landscape as a public resource implies that legal concepts are developed to explicitly define it, integrate it into spatial planning, and protect it when necessary [59]. Its planning and management have the special characteristics already mentioned, so "with regard to planning, landscape is considered as a resource, that in a wide sense, summarises and reflects the physical characteristics (biotic and abiotic ones) of a territory, as well as its anthropogenic influence" [57] (p. 79).

Different authors speak of the multi-functional landscape (e.g., Brandt \& Tress, 2000; Selman, 2002; Stockdale \& Barker, 2009) [60-62] for its simultaneous character (natural-social synergy), coexistence (different themes such as geography, ecology, economy, culture, history, aesthetics) and interaction (referring to interactions between socio-economic and physio-geographical systems. The multidimensionality of the landscape impetrates an interdisciplinarity in management and, in terms of sustainability, and makes indispensable the establishment of administrative institutions with characteristics that are cohesive, holistic, and deliberative where all agents intervene.

For this, an appropriate cartographic approach is essential for sustainable landscape planning, but summarising all the coexisting elements of a territorial unit (landscape units) on a cartography requires a complex methodology which significantly changes depending on the criterion used. This situation has resulted in a proliferation of scientific and technical landscape studies $[63,64]$ in which very different objectives and methodologies are explained.

The landscape's dynamic conception has consequences in cartography when transferring a landscape into a map: depending on the conceptual criterion and the purpose or the required use, a particular process or concept will be emphasised.

A broad conceptual discussion of the landscape term is outside the purview of this paper, but it is necessary to identify it as one of the reasons why new techniques to map a landscape are developing, many of which attempt to satisfy the need for integration of the landscape into land-use planning processes.

\section{Landscape-Mapping Methods}

In this work, five methods have been selected (see above) with which to study the landscape for territorial management. They are procedures with an eminently geographic approach, but their conceptual and methodological postulates are still very different.

In all of them, PG is decisive when developing landscape units, or working units, and in all of them the stated purpose is land-use planning in terms of sustainability and improvements in the quality of peoples' lives. Nevertheless, the place of PG in them is significantly different, as it acquires a diverse role regarding the human and cultural attributes. Additionally, the significance of physical geography's sub-disciplines is highly variable for several reasons. First, the initial concept of landscape will determine the resulting cartography. Second, the geographic areas will be important in the definition of landscape units: from extremely anthropogenic scenes to more remote and less-human-modified ones. A third factor is the source that motivates the development of these landscape studies, whether they are intended for scientific purposes or whether they are performed by technical teams whose assignment comes from a public administration. 
In the following part, we discuss the five methodologies (Table 1), including their origins, ideologies, and places where their methodological procedures have been applied. Considering the place of PG in these studies, these studies can be divided into three groups. The first one comprises the first two proposals (Van Zuidam-Verstappen and Russian geography). They both base their methodological procedure to map the landscape on entirely physical and geographic criteria. The asymmetry with the human geography is such that the latter is absolutely subordinated to the physical environment, and the landscape working unit is entirely subordinated to PG. The second group contains the methodologies of Landscape Character Analysis (LCA) and visual landscape units (VLUs). These procedures have become largely associated and widely adopted with the establishment of the European Landscape Convention (ELC)—which emphasizes sustainable development and territorial management-and their methodologies are based on the Convention's concept of landscape as: "an area, as perceived by people, whose character is the result of the action and interaction of natural and/or human factors" [65]. This definition has four aspects: (1) physical (an area), (2) holistic, (3) temporal (the result of the action and interaction of natural and/or human factors, developed through time), and (4) subjective-cultural (peoples' perceptions of the landscape) [66]. Therefore, it is a concept that integrates and attempts to balance the biophysical and the human. In the last proposal, landscape assessment with image pairs, the geographic asymmetry tends to human and cultural aspects, although PG is still present. The postulates that this methodology is based on are derived from the geography of perception with input from landscape ecology.

Table 1. Overview of the five methodologies discussed in terms of their conception of the landscape as an integrated area, the aspects of physical geography explicitly considered, the social, political, and economic factors considered, the units into which the landscape is delineated and/or mapped, and the scale at which the methodologies have been or are typically applied.

\begin{tabular}{|c|c|c|c|c|c|}
\hline Methodology & Conception of Landscape & $\begin{array}{c}\text { Aspects of Physical } \\
\text { Geography } \\
\text { Considered }\end{array}$ & $\begin{array}{l}\text { Social, Political, and } \\
\text { Economic Factors } \\
\text { Considered }\end{array}$ & $\begin{array}{l}\text { Landscape Units } \\
\text { Delineated }\end{array}$ & Scale \\
\hline $\begin{array}{l}\text { Geomorphological } \\
\text { landscape maps } \\
\text { based on } \\
\text { landforms }\end{array}$ & $\begin{array}{l}\text { Terrain features formed by } \\
\text { natural processes which have } \\
\text { a definable composition and } \\
\text { range of physical and visual } \\
\text { characteristics }\end{array}$ & $\begin{array}{l}\text { Topographic relief, } \\
\text { soil, hydrology, land } \\
\text { cover and vegetation }\end{array}$ & $\begin{array}{l}\text { No, but applied to } \\
\text { evaluate economic } \\
\text { possibilities }\end{array}$ & $\begin{array}{l}\text { Geomorphological } \\
\text { units }\end{array}$ & $\begin{array}{l}1: 25,000 \\
1: 50,000\end{array}$ \\
\hline $\begin{array}{c}\text { Geosystemic } \\
\text { landscape maps }\end{array}$ & $\begin{array}{l}\text { It has a systemic and } \\
\text { hierarchical character of the } \\
\text { natural components, and a } \\
\text { holistic perspective of the } \\
\text { geographic space }\end{array}$ & $\begin{array}{c}\text { Relief types, } \\
\text { lithology, climate } \\
\text { type }\end{array}$ & $\begin{array}{l}\text { No, but applied to } \\
\text { evaluate economic } \\
\text { possibilities }\end{array}$ & $\begin{array}{l}\text { Morpho-litho-climatic } \\
\text { units }\end{array}$ & $\begin{array}{l}1: 50,000 \\
1: 250,000\end{array}$ \\
\hline $\begin{array}{l}\text { Landscape } \\
\text { Character } \\
\text { Assessment }\end{array}$ & $\begin{array}{l}\text { An area, as perceived by } \\
\text { people, whose character is the } \\
\text { result of the action and } \\
\text { interaction of natural and/or } \\
\text { human factors }\end{array}$ & $\begin{array}{l}\text { Geology, land form, } \\
\text { soil, vegetation, land } \\
\text { cover, hydrology }\end{array}$ & $\begin{array}{l}\text { Yes, "cultural and social } \\
\text { factors", settlement } \\
\text { types, populations, } \\
\text { demography, } \\
\text { exploitation systems, } \\
\text { historical context }\end{array}$ & $\begin{array}{l}\text { Landscape } \\
\text { character units } \\
\text { (Landscape } \\
\text { character types } \\
\text { and areas) }\end{array}$ & Multiple \\
\hline $\begin{array}{c}\text { Landscape } \\
\text { studies based on } \\
\text { visual landscape } \\
\text { units }\end{array}$ & $\begin{array}{l}\text { An area, as perceived by } \\
\text { people, whose character is the } \\
\text { result of the action and } \\
\text { interaction of natural and/or } \\
\text { human factors }\end{array}$ & Topographic relief & $\begin{array}{c}\text { Yes, landscape } \\
\text { evaluation for planning, } \\
\text { social assessment }\end{array}$ & $\begin{array}{l}\text { Classified visual } \\
\text { landscape units }\end{array}$ & $1: 25,000$ \\
\hline $\begin{array}{l}\text { Landscape } \\
\text { assessment with } \\
\text { the test of image } \\
\text { pairs }\end{array}$ & $\begin{array}{l}\text { On the one hand the image of } \\
\text { a territory or phenosystem, } \\
\text { and on the other the relations } \\
\text { of interdependence of the } \\
\text { components that make up that } \\
\text { territory, or cryptosystem }\end{array}$ & $\begin{array}{l}\text { Topography relief, } \\
\text { hydrology, } \\
\text { vegetation, land } \\
\text { cover, climate, soil }\end{array}$ & $\begin{array}{l}\text { Yes, universal, cultural, } \\
\text { individual needs and } \\
\text { preferences }\end{array}$ & $\begin{array}{l}\text { Binary series of } \\
\text { landscape } \\
\text { preferences }\end{array}$ & Multiple \\
\hline
\end{tabular}

\subsection{Maps of Geomorphological Landscapes Based on Landforms}

The methodology for the generation of maps based on topographical landforms-designed by the geomorphologists van Zuidam, R. and Verstappen, H. [67-69], currently of the Faculty of Geo-Information Science and Earth Observation (ITC) of the University of Twente-has its 
epistemological basis in the German school, whose approaches are prominent in the history of geographical science. If we make a brief historical excursion intellectuel with respect to the landscape, we see that positivist geographer Siegfried Passarge (1866-1958) conceptualized the landscape as a branch of geography in deterministic terms [70], using some of the reflections of von Humboldt and later of Richtofen on the interconnections of physical-geographic variables, flowing into the idea of global landscape [71]. Another important author is Albrecht Penck (1858-1945), who understood the landscape as a spatial area that exhibits common relief features. From this school emerged a current of work with a strong reliance on geomorphology as the scientific basis of the cartography of the landscape.

Interpretation of the landscape from a geomorphological cartography permits us to study its past, present, and future evolution [72]. With geomorphology, the general principles that explain the geomorphological processes are established, and with this, the processes from which the forms of individual landscapes are derived [60,73], always based on a few decidedly deterministic postulates [74]. The evolutionary analysis of the landscape using geomorphological cartography generates synthetic cartographic representations that can facilitate environmental and sustainable territorial planning, portraying the landscape as a resource to value and preserve [72].

The method of van Zuidam, R. and Verstappen, H. [67-69] is based on geomorphological surveying and mapping techniques from interpretation of terrain forms on stereoscopic images, reorganizing and making the ground study more efficient. Geomorphological units are defined as terrain features formed by natural processes which have a definable composition and range of physical and visual characteristics. Analysing the landscape from the relief indicates the state of other components (e.g., soil), and allows one to determine the hydrological characteristics of a region, to diagnose the suitability of the land for certain uses, and find practical solutions to problems related to landscape degradation [67-69]. In spite of the clearly deterministic position of the methodology, the approach can be used to evaluate the socio-economic impact of land change.

The ITC method has been widely diffused as of present, with applications in geographic regions around the planet (Amazon, Alps, Antarctica, India). A case study is described below to better exemplify the approach [75]. The objective of the study in this example was to explore the usefulness of geomorphological mapping in the assessment of land suitability and land utilisation requirements for the potential diversification of economic activities in an indigenous forest community in Central Mexico. The community —encompassing ca. $190 \mathrm{~km}^{2}$ —is located in Central Mexico in a Quaternary volcanic region with a temperate seasonal climate.

\section{Method}

Landform analysis was considered as a basic step for the inventory of natural resources and a first approximation to the definition of landscape units (Figure 2). These units describe both the relatively stable land components (geology, terrain, and soils in an integrated manner), as well as the less stable components whose rate of change is much faster (vegetation and land-use/land-cover) [75].

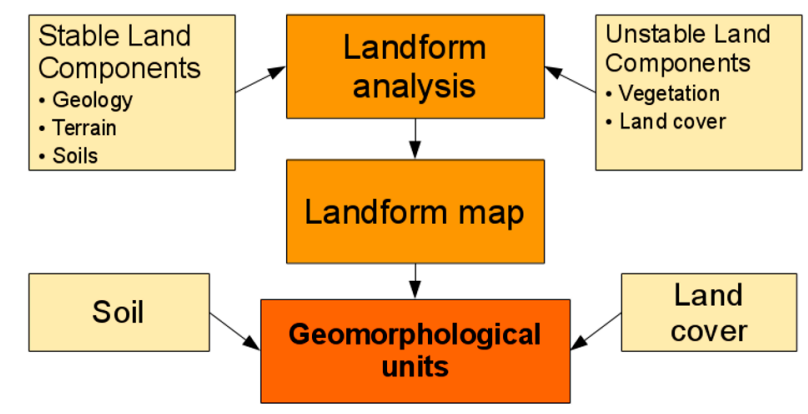

Figure 2. Overview of the process involved in the delineation of the landscape by geomorphological units based on landform. 
Geomorphological surveying and mapping were carried out using recent panchromatic, black and white aerial photo-interpretation and terrain analysis at approximate scales of 1:25,000 and 1:50,000, and standard terrain analysis techniques [67-69,75].

Landform mapping was based on the discrimination of volcanic cones and lava flows according to their relative age, and related units such as interlavic plains and volcanic foot-slopes. Slope morphology and morphometry, and drainage pattern analysis were derived from interpretation of topographic maps and digital elevation models (1:50,000 scale), as well as aerial photography. Landform delineation and related soil materials were intensively field-verified at 120 sites [75]. Geomorphological units were cartographically overlain on soils and land-cover data to quantify dominant soil and land-cover per landform category [75].

The geomorphological units described were used to (i) improve the mapping of forest quality units (site evaluation for forest use) and (ii) analyse the relationship between land suitability and land utilisation requirements; i.e., a land evaluation procedure for potential diversification of economic activities (including the implementation of ecotourism as a source of income). The final outcomes were the official forest management plan for the Ministry of the Environment and the implementation of a Geographic Information Systems (GIS) for data management and analysis operated by two members of the community [75].

\subsection{Geosystemic Landscape Maps}

Typological maps of physical-geographic landscapes have their origin in the Russian School of the end of the 19th century, also known as Complex Physical Geography.

Soviet geographer, biologist, and ichthyologist Lev Semenovich Berg (1876-1950) used the postulates that V. V. Dokuchaev (founder of genetic edaphology) developed for soil science, but adopted them to the concept of geographic landscape. The geographical landscape becomes the combination of phenomena in which the peculiarities of relief, climate, water, soil, vegetation, fauna and, to some extent, human activity are expressed. The landscape is, therefore, a naturally interconnected grouping of organic and inorganic factors in which change occurring in one feature begets change in all other characteristics [50]. Thus, Berg rejects the definition proposed by Albrecht Penck of the landscape as an area exhibiting common relief features (geomorphological landscape). With the contribution of Dokuchaev, the theoretical basis of the method is consolidated, establishing the geosystem theory in landscape science [76-79].

This approach would be adopted by geographers from Western Europe, for example in the French school of the twentieth century. The conceptual base of Georges Betrand and his GTP (Geosystem, Territory, Landscape) model is a reinterpretation of the Russian postulates, adapted to the geographic context of south-western Europe [80,81]. The application of Complex Physical Geography in the American tropical region by the Faculty of Geography of the University of Havana is another example of its utilisation in other geographic places of the world and corresponds to its spread throughout the American continents (Mexico, Brazil, Venezuela, Panama, and Guatemala). In the 21st century, Priego-Santander et al. (2010) [82] adapted the method for use with Geographic Information Systems (GIS) on semi-detailed scales $(1: 25,000,1: 50,000)$. These same adaptations have been recently applied in Spain, specifically in an area of the Iberian Mountain range [83].

Complex Physical Geography uses a hierarchical and systemic typology of natural components, and a holistic conception of the geographical space. The theoretical underpinning of its methodology is based on historical-evolutionary (each landscape unit is the result of the combined development of all its elements) and structural-genetic principles (the genetic process determines the arrangement of the natural elements), which is useful for landscape classification regardless of the scale of work and the taxonomic level represented [76-79,82-84]. 
Method

In a given study area, recognition of the relief types, their lithological composition, and the climatic type constitute the basis of geocomplex delimitation (Figure 3). These three cartographic elements are therefore necessary for the delineation of "Superior Landscape Units", and these three thematic layers are fused in practice. Briefly, the process is as follows:

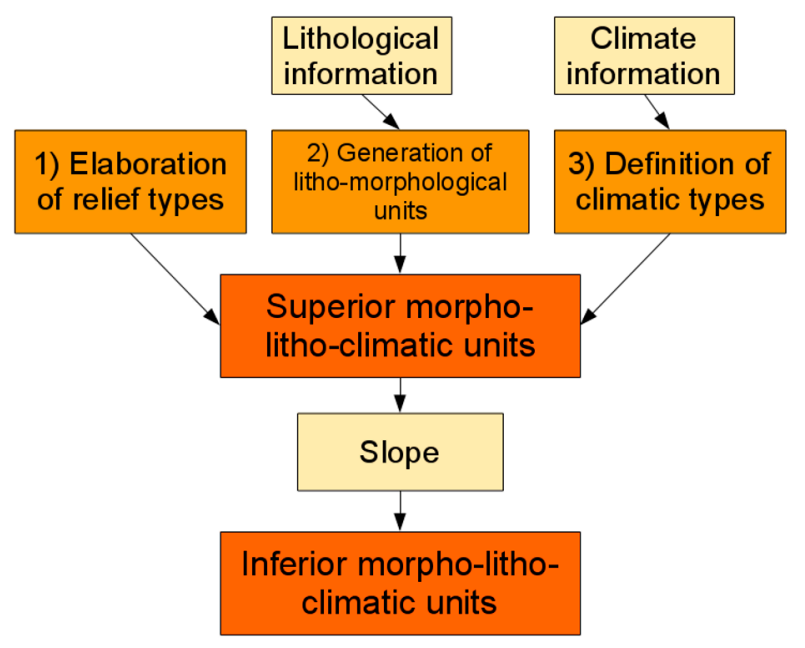

Figure 3. Overview of the process involved in the delineation of the landscape by morpho-litho-climatic units based on the postulates of the Russian school.

(1) Elaboration of relief types, achieved through vertical dissection (VD). This is a semi-automatic method designed to distinguish the different geographic features of a given area, defining variables for different types of relief (mountain, rolling hills, gently rolling plains, and plains) [82].

(2) Generation of lithological and morphological units. This is the combination of the results of the previous step with lithological information. This procedure defines the genesis of the relief types, and is useful for understanding land-cover characteristics.

(3) Definition of climatic type for the lithological and morphological units. Climatic information is combined with the results of the previous step.

The result of this process yields the morpho-litho-climatic units of the study area. Or, using the nomenclature of Complex Physical Geography, the Superior Landscape Units.

The Inferior Landscape Units are derived from the Superior Landscape Units using the morphological decomposition of the relief types, depending on the slope values within each Superior Unit. The resulting cartography depicts the landscape in terms of these Superior and Inferior Landscape Units.

\subsection{Landscape Character Assessment}

Landscape Character Assessment (LCA) is an assessment technique originally developed in the 1990s in the UK to identify the combination of biophysical and socio-cultural elements that define a given landscape and distinguish it from others $[85,86]$.

Following its development in England and Scotland, LCA has been formalized into the Living Landscapes Project to improve its consistency at multiple spatial scales [87], and forms of LCA have been applied in various other European countries, including Belgium [88], Denmark [89], Austria, Germany, Hungary, Portugal, Norway, The Netherlands, Spain, and Switzerland [90], as well as in New Zealand [91] and South Korea [92].

LCA purports to be a value-free form of assessment, in that it seeks to distinguish between different landscapes without designating one landscape as superior to another [85]. The emphasis on 
the integration of biophysical and social factors is based on the definition of landscape in the ELC, which defines it as stated in the introduction [65]. This emphasis by the ELC on the integration of human and non-human factors in the landscape is consistent with various other calls for stronger integration of physical and human geography, particularly in the pursuit of sustainability (e.g., Lave et al., 2014) [14].

From a conceptual point of view, LCA defines the landscape in terms of its character, defining landscape character as "a distinct and recognisable pattern of elements that occur consistently in a particular type of landscape. Particular combinations of geology, landform, soils, vegetation, land use, field patterns and human settlement create character. Character makes each part of the landscape distinct, and gives each its particular sense of place. Whether we value certain landscapes for their distinctiveness, or for other reasons, is a separate question" [85] (p. 9).

Method

Tudor (2014) [86] divides the landscape into three general components that LCA is designed to integrate: (1) natural (listed below); (2) cultural and social, consisting of land-use, settlement, enclosure, land ownership, and time depth; and (3) perceptual and aesthetic, consisting of memories, associations, preferences, tactile features, smells, sounds, and visual aspects [85,86].

The first phase of LCA begins with the determination of landforms units based on degrees of topographical homogeneity, which are estimated from topographic and hydrological data. The process continues with the overlay of other factors, which fall into two broad categories: (1) natural features, including geological features, soils, and land-use and vegetation cover; and (2) cultural and social factors, including settlement types, populations, demographic factors, exploitation systems, and historical contexts. Of these, relief, geology, land-use, and settlement types are considered the basic factors in the determination of landscape units. The result of this primary phase is a preliminary version of landscape types in the study area and their division into landscape units.

The second phase of LCA involves field work to assess the perceptual and aesthetic aspects of the landscape units (Figure 4).

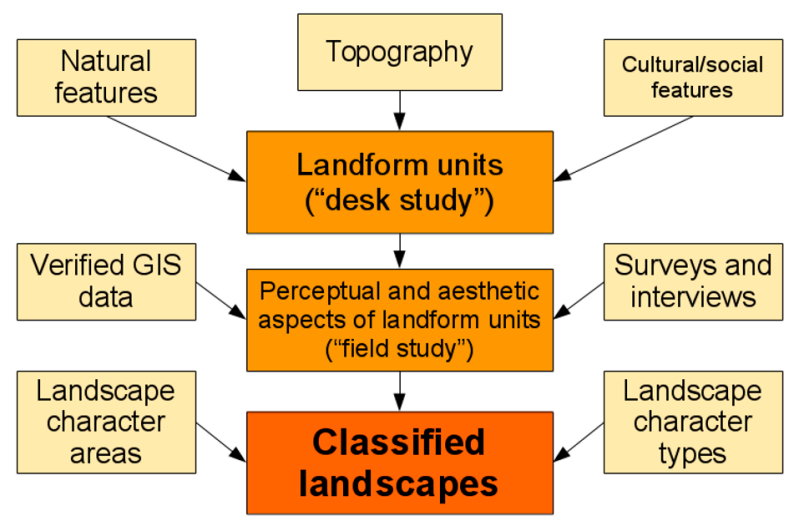

Figure 4. Overview of the process involved in the classification of the landscape into different character units in landscape character assessment.

The information obtained in the first two phases is used to undertake landscape classification. This classification involves the division of the landscape into distinctive areas that are both recognizable and internally homogeneous in terms of landscape character (i.e., landscape character areas). These areas are then grouped based on landscape features shared in a basic landscape typology (landscape character types). This classification process is based on the identification of patterns produced by the interactions of natural and human factors, and can be performed at multiple scales. Thus, while the geophysical landscape may be treated as a backdrop to social and perceptual factors, it still plays a central role in LCA. 
The result is a hierarchical landscape assessment, with perceptual aspects considered within the context of the underlying biophysical and socio-economic factors.

\subsection{Landscape Studies Based on Visual Landscape Units}

Like LCA, landscape maps based on Visual Landscape Units (VLUs) can be used to meet the assessment standards established by the ELC. The method's epistemological background comes from the Technical School of Engineering of the Polytechnic University of Madrid, from a research group led by Professor Ángel Ramos Fernández, who developed the delimitation of landscape units through visual enclosures and many of the related visibility studies [93-95]. This methodology was applied to the production of landscape maps for the pubic administrations of some Spanish autonomous communities, particularly La Rioja (2004) [94] and Aragon (2007-2013) [96]. In Mexico, there has also been some scientific work in the central region of the country using this methodology $[97,98]$.

The method of landscape assessment based on VLUs has a strong imperative to relate landscape and spatial planning, so that the former is an important factor to consider when designing and implementing the processes of the latter.

Method

There are three phases to landscape analysis by VLU (Figure 5):

(1) VLU delimitation. This entails delimiting VLUs based on the preferential criteria of visual enclosures. A VLU is a landscape unit that can be defined as "the visually interconnected area within which a viewer is able to see most of that portion of the territory and not that of surrounding areas" [96]. This reference to vision, or absence thereof, in specific spaces leads to a delimitation process by existing visual enclosures which, at the same time, coincide with certain topographic and hydrological boundaries. In mountainous areas, the relief acts as a visual enclosure, so that water borders determined by the orography define the borders of each VLU [99]. This delimiting technique enables determination of landscape units of appropriate sizes for landscape and territorial management. Small VLUs will be more suitable for this management, since they will enjoy greater precision with regards to landscape characterization than would larger landscape units. For the same reason, landscape and territorial management proposals may be more realistic in small VLUs, since they will generally be more internally homogeneous than larger landscape units.

The VLU method is more difficult to apply in areas with more shallow relief or areas that are entirely flat. In these cases, other delimitation criteria need to be applied, with landscape units that are not visually enclosed. Secondary topographic boundaries, clear changes in land use, and artificial elements of great magnitude such as embankments, walls, assorted infrastructures, etc., can be used in this delimitation, with the aim of adjusting the working methods to the territorial reality.

(2) Determination of landscape types. Landscape types are derived from the combination of biotic and abiotic elements that shape the landscape, and its characterization is based on the most significant natural and human variables that coexist in a given territory.

(3) Analysis and assessments applied to different VLUs. Several key features in landscape studies applied to territorial planning must be considered in this phase. Here, the Landscape Maps of Aragon are a relevant example [96]. They include the aforementioned VLU delimitation and the determination of existing landscape types, which are accompanied by the relation and classification of the negative factors that affect those landscapes and the catalogue of existing unique elements, as well as the cartographic analyses of visibility.

Together with other complementary variables, quality and fragility act as a basis for the diagnosis of the aptitude of each VLU for different uses. The valuation of these qualities is made for every VLU, so that these VLUs can constitute landscape management units $[96,98,100]$. 


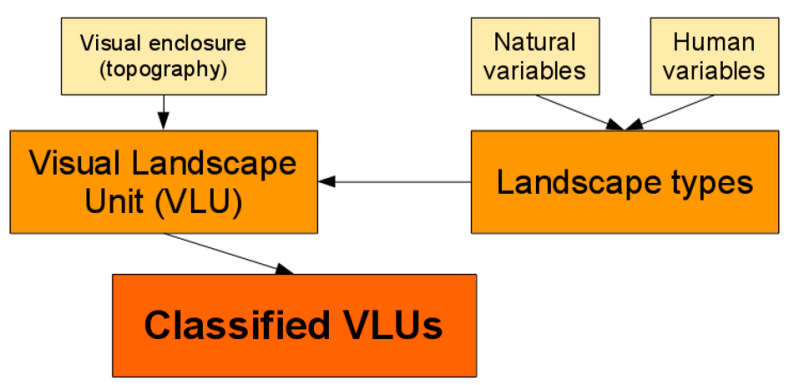

Figure 5. Overview of the process involved in the delineation and classification of the landscape based on visual landscape units (VLUs).

\subsection{Landscape Assessment with the Comparison of Image Pairs}

The assessment and management of the landscape based on pairs of images depicting different landscapes or elements therein was developed in the 1970s at the University of Seville and the Department of Ecology of the Autonomous University of Madrid within the line of research established by Professor Fernando González Bernáldez. This method has been applied in both basic and applied research in Spain and in several Latin American countries.

The main objective has been to identify the biological roots of the meaning that natural environments have for human beings [101], which González Bernáldez called the "affective adaptation to the environment" [102] and "the search for patterns of preferential reaction to the environment, in order to define the most relevant characteristics - both landscape and subjects—-that influence the same, as a means of supporting educational actions and the management of goods or natural resources" [101] (p. 5).

Landscape is understood as a duality; on the one hand, the image of a territory or phenosystem, and on the other the relations of interdependence of the components that make up that territory, or cryptosystem. In 1973, González Bernáldez and his colleagues defined the landscape as "the multi-sensory perception of a system of ecological relations" [102].

The use of the information and the interpretation of the natural environment is linked to the evolution and survival of the human beings in it [103] (p. 134). Therefore, the interpretation of landscape elements has been vital, as, for example, the preference for landscapes with elements with relief that allow one to see without being seen to define strategies for hunting, refuge, etc.; and the presence of water and vegetation to guarantee access to water, food, and construction materials. These ideas are developed and consolidated from works of Appleton [104], Gibson [105], and Kaplan and Kaplan [106].

From all this we postulate a triple influence in the assessment of the landscape as a resource: (a) universal or adaptive, common to all human beings and related to their ability to interpret the environment for the survival of the species; (b) cultural, based on the experience of the social group from trial-and-error; and (c) individual, based on individual experience and personality $[107,108]$.

\section{Method}

The team uses methods based on the hierarchical superposition of thematic layers following the landscape-planning of McHarg's (1969) [109] works. These layers make up the main elements of the landscape, and their reading in reverse order allows the interpretation of the territory, reflecting the processes resulting from the historical interaction between nature and culture. The sum and interaction between physical factors, biotic factors, and human activity have given rise to the present scene (Figure 6). For the proper representation of the diversity of landscapes, a differentiation of the territory into homogeneous units is necessary $[82,84,110]$, which allows researchers to compose paired photo tests to evaluate the territory. From the defined landscape units, the researchers construct a test 
of pairwise images, in which they pair each landscape unit with another, and ask the subject which is the preferred image of each pair.

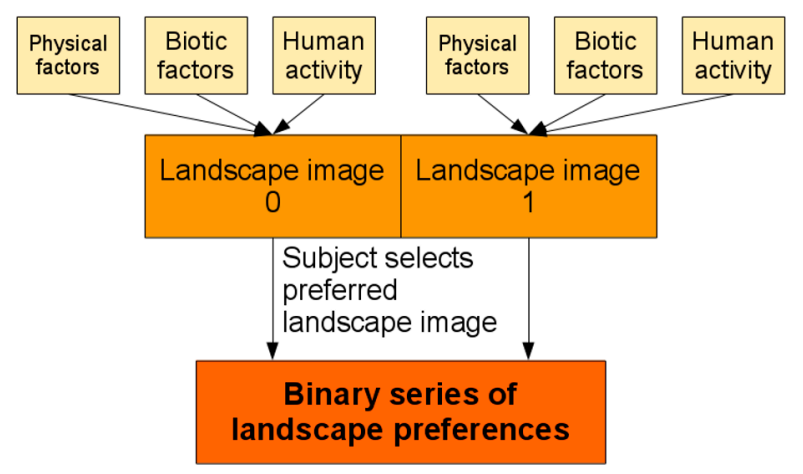

Figure 6. Overview of the process involved in the evaluation of different landscapes based on paired-image tests.

The test of image pairs allows us to integrate a wide range of landscapes and evaluate them in an absolute, coherent, and comparable scale [101] (p. 25), and survey respondents are simply requested to choose which image they like the most of each pair. The answers obtained are binary $(0$ or 1$)$ and can be analysed with descriptive and multivariate statistics, which allows the establishment of the structure of the preferences. The approach can be applied at different scales, but is obviously more effective at finer scales, where the visual landscape is more readily captured in images.

\section{Discussion}

Each of the methodologies reviewed here seeks to contribute to sustainable land-management by satisfying the need for an integrated approach to landscape analysis that combines physical and social factors. The landscape is considered an optimal working unit for a sustainable management due to its synthetic character, but the extent to which physical and social factors are explicitly included and their relative weightings vary substantially, resulting in highly diverse methodological and cartographic procedures. Considering this circumstance based on the role that PG plays in these different methodologies is helpful in understanding this diversity and that no single method of reading the landscape is the only correct one.

\subsection{Geomorphic and Geosystemic Landscape Maps}

We have presented the methodology of Van Zuidam as representative of the current of landscape-mapping under geomorphological criteria with widespread application at present in diverse geographical areas around the world. There are other equally efficient approaches in this vein, such as the Commonwealth Scientific and Industrial Research Organization (CSIRO). The geomorphological approach permits a dynamic analysis of the landscape that highlights its evolutionary character, which is fundamental to thinking in terms of sustainability.

The postulates of Van Zuidam and Priego-Santander do not consider the human aspect when mapping the landscape, which can be understood as a subordination of society to physical-geographical units. Vegetation and land uses are "environmental characteristics and not differential factors: they are the consequence and not the cause" [82] (p. 63). As we said, the method of Van Zuidam has been employed in widely different environments; for example, in predominantly remote areas with little direct anthropogenic influences, such as Antarctica [111], or remote parts of the Amazon [112]. In this sense, these two methodologies focus on the biogeophysical aspects of sustainability at the expense of the human dimensions involved. On the other hand, in the case study discussed above (see Section 2.1), landscape surveying and mapping techniques based on geomorphological analysis, coupled with GIS and remote sensing procedures, were conducted in an indigenous community in 
a semi-peripheral country to provide tools to the community for sustainable management [75]. In this case, these tools were used directly by the managers of the resources, illustrating how local communities may adequately combine historic traditions with current technology and geomorphological surveying to plan sustainable agroforestry and natural-resource management. In this context, geomorphological knowledge must be user-oriented to ensure that the knowledge generated contributes to participatory planning and management for sustainability [113]. Because of the nature of landforms and their role as a landscape component, geomorphological surveying has proven extremely useful for resource inventory, analysis and management in peripheral areas where resource knowledge is scarce, outdated, or even absent [75].

The physical-geographic landscape maps of the Complex Physical Geography were originally designed to be used throughout Russia's vast territory, with the objective of having a synthetic cartography of its landscape varieties. The adaptation in Western Europe of the methodology for use with GIS by Priego-Santander et al. (2010) [82] under the same epistemological postulates made possible its application in other regions of the world; for example, in Mexico and Cuba, two countries whose high levels of biodiversity are reflected on landscape maps at even local scales. On the other hand, Franch-Pardo et al. (2015) [83] found that this methodology did not reflect the prominent landscape diversity in the Martin River basin (Iberian System, Spain), a less diverse area in geo-ecological terms with strong historical anthropogenic influences, despite its rural nature. This suggests that physical-geographical maps may be more appropriate in areas with a certain level of landscape-level heterogeneity, and yield less clear results in areas which do not have those characteristics. The cartographic mapping of the Martin River at a 1:25,000 [100] scale also indicated another factor with implications for sustainable land management. The high variability of the resulting landscape units $\left(7.3 \mathrm{~km}^{2}\right.$ to $\left.0.1 \mathrm{~km}^{2}\right)$ were difficult to operationalise in management.

Although the physical factors predominate over social and cultural ones in these two methodologies, they both share the stated objective of promoting sustainable land management that benefits the inhabitants of the areas studied. This latter assertion links with the scientific currents that interpret the study of sustainability as the prioritization of the Earth's biophysical systems (e.g., Schellnhuber et al., 2004) [114].

The extent to which they are able to achieve this objective, however, is limited by the extent to which land management reflects structures of power and inequality that these methodologies do not address. For this reason, Shaw and Olfield (2007) [50] define these types of methodologies as technocentric. However, as we acknowledge, new works are integrating Russian postulates with human variables (e.g., Franch-Pardo et al., 2017) [100]. These circumstances will allow us to expand the application of these postulates to issues pertaining to sustainability (Huggett and Perkins, 2004 cited in Shaw and Olfield, 2007) [50].

\subsection{Landscape Character Assessment and Landscape Studies Based on Visual Units}

LCA and the VLU have both been proposed as responses to the mandates of the European Landscape Convention, and respond to its pluralistic conception of landscape and the mandates that physical and social aspects must be integrated for sustainable landscape-management [115]. LCA is primarily envisioned as an input into sustainable landscape planning and management. Swanwick (2002) [85] proposes that LCA contributes to the objectives of "environmental protection" and "prudent resource use" in the UK government's strategy for sustainable development (Department of the Environment, Transport and the Regions, 1999). Applications of LCAs outside the UK have similarly emphasized their role in management and conservation of landscapes for biodiversity as well as cultural heritage (e.g., Eetvelde and Antrop, 2009) [88]; Kim and Pauleit, 2007 [92]). Tudor (2014) [86] contends that LCA is an open and transparent form of landscape assessment that can provide important baselines against which land change can be managed, and identifies potential areas for stakeholder involvement at various phases of the process. 
The method based on VLU has been specifically designed to provide a landscape approach to land management. Its advantage primarily lies in the correspondence between the landscape units it generates and the delimitation of management territories. The small sizes of the VLUs facilitate decision making in specific territories, thereby reflecting an important practical need in land management. In Aragon, Spain, the method has been successfully used to elaborate a series of "Landscape Maps" for management. These maps strictly observe article two of the European Landscape Convention, related to its functional scope, which states that this Convention applies to the entire territory of the Parties and covers natural, rural, urban, and peri-urban areas [100]. Thus, it applies to landscapes that may be considered valuable for sustaining biodiversity as well as heavily transformed or ecologically depleted landscapes [65]. The Aragon Landscape Maps [96] cover all the territorial areas within which all existing landscapes are analysed, described and classified, regardless of their characteristics. Their primary purpose is to serve as supporting documents in spatial planning policies in the territories concerned. In this sense, these maps provide three main benefits: (1) detailed cartography, as these maps provide new cartographic information at a semi-detailed scale of 1:25:000; (2) information potentially useful to local urban development in the assignation of land uses and the activities to be realized therein, as these maps indicate higher quality (in both social and ecological terms) landscapes where limitations on certain land-altering activities is advisable; and (3) a basis for landscape impacts studies, as they indicate areas where landscape values suggest that a Landscape Impact Study should be carried out before certain actions are undertaken.

These expert-based approaches to landscape assessment-also called indirect methods-have been called into question, however, as both their production and application tend to be dominated by professionals rather than the communities in the target landscapes $[89,116]$, and their role in policy tends to follow the "deficit model", which posits policy-makers as neutral guardians of the public trust who simply need to be provided with reliable scientific information in order to make decisions that contribute to sustainability [117]. In a review of 52 LCAs undertaken in the UK between 2007 and 2011, for instance, Butler and Berglund (2014) [118] found that many of them limited public input to responses to expert views of the landscape, with only one quarter of the assessments involving significant public engagement according to the authors' criteria. James and Gittins (2007) [119] also caution that, in addition to economic resources, information availability and community skill-bases pose significant challenges to the use of LCA by communities to define and defend their sense of place in a manner consistent with the pursuit of sustainability. Charges that LCA further contributes to exclusion and technocratic governance are bolstered by adaptations of the process that seek to improve its "scientific rigour" by replacing public perceptions of landscape character with quantifiable indicators (e.g., Ode et al., 2008 [120]). Thus, while LCA potentially offers tools for more democratic and sustainable landscape-planning and governance [121], this potential is frequently curtailed by politico-economic factors that generally lie outside the purview of the methodology.

Methods that integrate public perspective are essential to sustainable management of the landscape [122]. The ELC itself advocates attending to citizen perception through integrated and multifunctional management. In this paper, we have presented a methodology with a great deal of epistemological baggage, although other, equally esteemed procedures (e.g., visitor-employed photography, VEP) exist [123].

\subsection{Landscape Assessment Based on Image Pairs}

The image pair test is based on the population's perceptual valuation. Its main interest is in "the search of a synthesis between the understanding of the ecological processes underlying landscapes and the comprehension of the key factors that make a place valuable for individuals and society". This has been denominated "landscape decoding" in the literature [124] (p. 127), which describe it as useful for "a better understanding and management of natural resources" [102] (pp. 11-12). Despite the differences related to the influences of cultural background and personal experience on each person's perception of the landscape, some common patterns related to landscape preferences that pertain to 
sustainability appear to exist. These primarily involve topographic relief, presence of vegetation, and water, all of which are said to be related to species-level memory based on the need to increase survival probabilities [101,102,125]. From these commonalities, three general similarities emerge when referring to landscape preferences: (1) topophilia, or affinity for landscapes with significant topographic relief; (2) phytophilia, or preference for landscapes with vegetation; and (3) hydrophilia, or preference for landscapes with clean and moving waters. Given its reliance on stated preferences in the assessment of landscapes, this methodology successfully illustrates the extent to which the visual landscape can contribute to human well-being in ways not directly related to basic material requirements (air, food, water; [126]). The primary weakness of this methodology in terms of its contribution to sustainability, however, is the rather tenuous relationship between individual preference and underlying ecological conditions. The preference for a vegetated landscape, for instance, does not necessarily imply a distinction between endemic and exotic vegetation, nor the extent to which such vegetation is appropriate to the landscape in question (see, for instance, Robbins' (2007) [127] analysis of the social and ecological contradictions of the popularity of European-style lawns in the USA).

\subsection{Landscape Assessment for Sustainable Management in Context}

The economic, political, and social context of land management in terms of the geographical landscape is another key aspect of this discussion that affects the contribution of the different methodologies to the three dimensions of sustainability (environmental change, social justice, economic equality) within the capital system. Mexico, for instance, is a country with substantial natural resources in its rural areas but, at the same time, with many conflicts between local communities and extractive interests [128], high levels of social inequality and marginalization, widespread political corruption, and a large geographic area that gives a greater semantic prominence to the concept of remoteness [129]. In these cases, a landscape approach to management can be useful in evaluating environmental impacts of extraction, and can be used to defend the rights of rural communities who are frequently excluded from decision-making and face numerous threats when voicing opposition [130], thereby contributing to social justice and economic equality as well as helping to mitigate anthropogenic environmental change. Within these contexts, landscape assessment for sustainable management can also help to describe the geographical reality. In rural areas lacking detailed studies of environmental variables, landscape cartography can help residents to optimize land-use decisions based on various criteria within the three dimensions of sustainability. In these rural and remote areas, where much of the conflicts over sustainability and management centre on the availability and exploitation of natural resources, valuations of the landscape's aesthetic aspects can be expected to be of secondary importance. Thus, studies conducted in Mexico using perceptual parameters have been undertaken mainly in peri-urban, tourist, and protected areas, where the visual component is valued more heavily for the maintenance of existing landscape qualities.

We conclude that territorial planning based on the integrated and multi-functional landscape is an important policy tool for decision-making based on sustainability criteria. We close the discussion with one last thought: the interaction between landscape and sustainability is reciprocal, in accord with Scott's (2011) [131] statement that strategies for sustainable communities, with public participation, are potential tools to facilitate landscape planning.

\section{Conclusions}

Sustainable territorial planning entails applied, integrated geography, but this does not necessarily imply a single unitary methodology. On the one hand, the methodological diversity in landscape cartography must also be considered in the context of the wide diversity of landscapes on the planet, as well as the processes that form them [132]. Therefore, the methodology must be appropriate to the social, physical, and geographical context of the study area, and to its intended application.

On the other hand, we have also discussed how the economic, social, and political contexts of the countries working with landscape cartography influence the selection of the methodology used. 
This nexus of biogeophysical and social factors illustrates the need to maintain a careful dialectical balance between determinism and constructionism when dealing with the complex interactions between human and non-human systems [42]. On the one hand, the methodologies discussed in this paper generally avoid falling into radical constructionism, and therefore social monism, as even the methodology most heavily based on social evaluation-image-pair testing-at least attempts to link human preferences to an underlying reality. However, as discussed in the introduction, land management from the landscape perspective tends to rely heavily on deterministic, post-positivist epistemological positions whose attempts at ethical neutrality frequently leads them to neglect underlying political and socio-economic factors, with profound implications for both the ecological and social viability of sustainable management proposals [48]. In addition to structural, political, and economic factors that tend to influence decision-making, this lack of epistemological reflexivity can help to explain why, as Liu et al. (2014) [4] note, many environmental assessments for sustainable management fail to adequately address environmental protection, social justice, and economic equality simultaneously. Programs propounding ecological sustainability that neglect these dimensions of social justice and economic equality undermine the possibility of long-term social sustainability, given humanity's tendency to resist and undermine unjust social orders [133]. Rather than reject such incomplete methodologies outright, however, we propose that they be used for the valid, if partial, insights they can still provide in the construction of a geography with a "dual methodological commitment to scientific integrity and non-neutrality" [48] (p. 9). This pursuit of an emancipatory geography is fundamental to the pursuit of human sustainability in all three respects.

Author Contributions: Iván Franch-Pardo co-ordinated contributions from other authors, provided most of the background information in the introduction, as well as the discussion, and provided the information on geosystemic landscape maps. Brian M. Napoletano provided the information on Landscape Character Analysis, and the text in the introduction and conclusions regarding sustainability and translated most of the text into English. Gerardo Bocco provided the information on mapping geomorphological landscapes based on landforms and helped to evaluate the manuscript in its entirety. Sara Barrasa provided the information on landscape assessment based on image-pair tests. Luis Cancer-Pomar provided the information on landscape mapping using visual landscape units.

Acknowledgments: The authors thank the first and third anonymous reviewers for their constructive input, which has helped to strengthen the paper considerably.

Conflicts of Interest: The authors declare no conflict of interest.

\section{References}

1. Mansfield, B. Sustainability. In A Companion to Environmental Geography; Castree, N., Demeritt, D., Liverman, D., Rhoads, B., Eds.; Wiley-Blackwell: West Sussex, UK, 2009; pp. 37-49.

2. Sneddon, C.S. 'Sustainability' in ecological economics, ecology and livelihoods: A review. Prog. Hum. Geogr. 2000, 24, 521-549. [CrossRef]

3. Agyeman, J.; Evans, B. Environmental Quality and Human Equality. Local Environ. 2002, 7, 5-6. [CrossRef]

4. Liu, L.; Liu, J.; Zhang, Z. Environmental Justice and Sustainability Impact Assessment: In Search of Solutions to Ethnic Conflicts Caused by Coal Mining in Inner Mongolia, China. Sustainability 2014, 6, 8756-8774. [CrossRef]

5. Agyeman, J. Sustainable Communities and the Challenge of Environmental Justice; NYU Press: New York, NY, USA, 2005; 256p.

6. Turner, B.L., II; Moran, E.F;; Rindfuss, R.R. Integrated land-change science and its relevance to the human sciences. In Land Change Science: Observing, Monitoring and Understanding Trajectories of Change on the Earth's Surface; Gutman, G., Janetos, A.C., Justice, C.O., Moran, E.F., Mustard, J.F., Rindfuss, R.R., Skole, D.L., Turner, B.L., Cochrane, M.A., Eds.; Springer: Dordrecht, The Netherlands, 2004; pp. 431-447.

7. Antrop, M. Sustainable landscapes: Contradiction, fiction or utopia? Landsc. Urban Plan. 2006, 75, 187-197. [CrossRef]

8. Castree, N.; Demeritt, D.; Liverman, D. Introduction: Making sense of environmental geography. In A Companion to Environmental Geography; Castree, N., Demeritt, D., Liverman, D., Rhoads, B., Eds.; Wiley-Blackwell: West Sussex, UK, 2009; pp. 1-15. 
9. Leng, S.; Lin, C.; Yang, Y.; Guo, Z.; Zheng, Y.; Yang, L.; Li, B. Environmental geography. In The Geographical Sciences during 1986-2015, From the Classics to the Frontiers; Leng, S., Gao, X., Pei, T., Zhang, G., Chen, L., Chen, X., He, C., He, D., Li, X., Lin, C., et al., Eds.; Springer: Singapore, 2017; pp. 167-202.

10. Harrison, S.; Massey, D.; Richards, K.; Magilligan, F.J.; Thrift, N.; Bender, B. Thinking across the divide: Perspectives on the conversations between physical and human geography. Area 2004, 36, 435-442. [CrossRef]

11. Pattison, W.D. The four traditions of geography. J. Geogr. 1964, 63, 211-216. [CrossRef]

12. Sauer, C.O. The Morphology of Landscape; University of California: Oakland, CA, USA, 1925; pp. 19-53.

13. Schnaiberg, A.; Gould, K. Environment and Society: The Enduring Conflict; St. Martin's Press: New York, NY, USA, 1994; p. 280.

14. Lave, R.; Wilson, M.W.; Barron, E.S.; Biermann, C.; Carey, M.A.; Duvall, C.S.; Johnson, L.; Lane, K.M.; McClintock, N.; Munroe, D.; et al. Intervention: Critical physical geography. Can. Geogr. 2014, 58, 1-10. [CrossRef]

15. Diamond, J. Guns, Germs, and Steel; W.W. Norton \& Company: New York, NY, USA, 1999; 496p.

16. Wilson, E.O. The Future of Life; Vintage Books: New York, NY, USA, 2003; 229p.

17. Demeritt, D. What is the 'social construction of nature'? A typology and sympathetic critique. Prog. Hum. Geogr. 2002, 26, 767-790. [CrossRef]

18. Foster, J.B. Marxism in the Anthropocene: Dialectical Rifts on the Left. Int. Crit. Thought 2016, 6, 393-421. [CrossRef]

19. Turner, B.L., II; Lambin, E.F.; Reenberg, A. The emergence of land change science for global environmental change and sustainability. Proc. Natl. Acad. Sci. USA 2007, 104, 20666-20671. [CrossRef] [PubMed]

20. Turner, B.L., II; Robbins, P. Land-Change Science and Political Ecology: Similarities, Differences, and Implications for Sustainability Science. Annu. Rev. Environ. Resour. 2008, 33, 295-316. [CrossRef]

21. Bastian, O.; Krönert, R.; Lipský, Z. Landscape diagnosis on different space and time scales-A challenge for landscape planning. Landsc. Ecol. 2006, 21, 359-374. [CrossRef]

22. Burinskiene, M.; Rudzkiene, V. Future insights, scenarios and expert method application in sustainable territorial planning. Technol. Econ. Dev. Econ. 2009, 15, 10-25. [CrossRef]

23. Gómez-Orea, D.; Gómez-Villarino, A. Ordenación Territorial; Mundi-Prensa: Madrid, Spain, 2013; p. 543.

24. Skole, D.L. Geography as a great intellectual melting pot and the preeminent interdisciplinary environmental discipline. Ann. Assoc. Am. Geogr. 2004, 94, 739-743.

25. Chartier, D.; Rodary, E. Géographie de l'environnement, écologie politique et cosmopolitiques. L'Espace Politique. Revue en Ligne de Géographie Politique et de Géopolitique 2007. [CrossRef]

26. Bocco, G.; Urquijo, P.S. Geografía ambiental: Reflexiones teóricas y práctica institucional. Región y Sociedad 2013, 25, 75-102. [CrossRef]

27. André, M.F. From physical geography to environmental geography: Bridges and gaps (a French perspective). Can. Geogr. 2017, 61, 136-142. [CrossRef]

28. Baerwald, T.J. Prospects for geography as an interdisciplinary discipline. Ann. Assoc. Am. Geogr. 2010, 100, 493-501. [CrossRef]

29. Erickson, R.A. Geography and the changing landscape of higher education. J. Geogr. High. Educ. 2012, 36, 9-24. [CrossRef]

30. Bocco, G.; Priego, A.; Cotler, H. The contribution of physical geography to environmental public policy development in Mexico. Singap. J. Trop. Geogr. 2010, 31, 215-223. [CrossRef]

31. Strahler, A. Introducing Physical Geography, 6th ed.; John Wiley \& Sons: New York, NY, USA, 2013; p. 550.

32. National Research Council (NRC). Rediscovering Geography: New Relevance for Science and Society; National Research Council, Rediscovering Geography Committee, National Academies Press: Washington, DC, USA, $1997 ; 248 \mathrm{p}$.

33. Inkpen, R.; Wilson, G. Science, Philosophy and Physical Geography; Routledge: London, UK, 2013.

34. Massey, D. Space-time, 'science' and the relationship between physical geography and human geography. Trans. Inst. Br. Geogr. 1999, 24, 261-276. [CrossRef]

35. Clifford, N.; Cope, M.; Gillespie, T.; French, S. (Eds.) Key Methods in Geography, 2nd ed.; Sage: London, UK, $2016 ;$ p. 545.

36. Cataldo, A.; Rinaldi, A.M. An ontological approach to represent knowledge in territorial planning science. Comput. Environ. Urban Syst. 2010, 34, 117-132. [CrossRef] 
37. Von Bertalanffy, L. General System Theory: Foundations, Development, Applications; Braziller: New York, NY, USA, 1968; 295p.

38. Antrop, M. Geography and landscape science. Belgeo Revue Belge de Géographie 2000, 1-2-3-4, 9-36. [CrossRef]

39. Antrop, M. Background concepts for integrated landscape analysis. Agric. Ecosyst. Environ. 2000, 77, 17-28. [CrossRef]

40. Zoido-Naranjo, F. Landscape and spatial planning policies. In Landscape and Sustainable Development: Challenges of the European Landscape Convention; Prieur, M., Luginbuehl, Y., Zoido Naranjo, F., De Montmollin, B., Pedroli, B., Van Mansvelt, J.D., Durousseau, S., Eds.; Council of Europe: Strasbourg, France, 2005; pp. 55-79.

41. Lane, S.N. Slow science, the geographical expedition, and Critical Physical Geography. Can. Geogr. 2017, 61, 84-101. [CrossRef]

42. Levins, R.; Lewontin, R. The Dialectical Biologist; Harvard University Press: Cambridge, MA, USA, 1987; 336p.

43. Peet, R. Global Capitalism: Theories of Societal Development; Routledge: New York, NY, USA, 1991; 206p.

44. Foster, J.B. Marx's Ecology: Materialism and Nature; Monthly Review Press: New York, NY, USA, 2000; 200p.

45. Napoletano, B.M.; Paneque-Gálvez, J.; Vieyra, A. Spatial Fix and Metabolic Rift as Conceptual Tools in Land-Change Science. Cap. Nat. Soc. 2015, 26, 198-214. [CrossRef]

46. Wolf, E.R. Facing Power-Old Insights, New Questions. Am. Anthropol. 1990, 92, 586-596. [CrossRef]

47. Sayer, A. Realism and Social Science; SAGE Publications: London, UK, 2000; 224p.

48. Harvey, D. On the History and Present Condition of Geography: An Historical Materialist Manifesto. Prof. Geogr. 1984, 36, 1-11. [CrossRef]

49. Harvey, D. Justice, Nature and the Geography of Difference; Wiley-Blackwell: West Sussex, UK, 1997; 488p.

50. Shaw, D.J.; Oldfield, J.D. Landscape science: A Russian geographical tradition. Ann. Assoc. Am. Geogr. 2007, 97, 111-126. [CrossRef]

51. Real Academia Española. Nuevo Tesoro Lexicográfico de la Lengua Española. Available online: http: / / ntlle.rae.es/ntlle/SrvltGUILoginNtlle (accessed on 1 April 2017).

52. Claval, P. Geographie Culturelle: Une Nouvelle Approche des Societes et des Milieux; Armand Colin: Paris, France, 2003; 352p.

53. Cosgrove, D.E. Social Formation and Symbolic Landscape, 2nd ed.; University of Wisconsin Press: Madison, WI, USA, 1998.

54. Tuan, Y.F. Space and Place: The Perspective of Experience; University of Minnesota Press: Minneapolis, MN, USA, 1977.

55. Gregory, D.; Johnston, R.; Pratt, G.; Watts, M.; Whatmore, S. (Eds.) The Dictionary of Human Geography; Wiley-Blackwell: London, UK, 2009; 1072p.

56. Turner, M.G.; Gardner, R.H.; O'Neill, R.V. Landscape Ecology in Theory and Practice: Pattern and Process; Springer: New York, NY, USA, 2001; 401p.

57. Cancer-Pomar, L. La Degradación y la Protección del Paisaje; Cátedra: Madrid, Spain, 1999; 248p.

58. Bryant, R.L.; Bailey, S. Third World Political Ecology; Routledge: New York, NY, USA, 1998; 256p.

59. Tress, B.; Tress, G.; Decamps, H.; D'Hausteserre, A.M. Bridging human and natural sciences in landscape research. Landsc. Urban Plan. 2001, 57, 137-141. [CrossRef]

60. Brandt, J.; Tress, B. Multifunctional Landscapes: Interdisciplinary Approaches to Landscape Research and Management. In Proceedings of the International Conference on Multifunctional Landscapes: Interdisciplinary Approaches to Landscape Research and Management, Roskilde, Denmark, 18-21 October 2000.

61. Selman, P. Multi-function landscape plans: A missing link in sustainability planning? Local Environ. 2002, 7, 283-294. [CrossRef]

62. Stockdale, A.; Barker, A. Sustainability and the multifunctional landscape: An assessment of approaches to planning and management in the Cairngorms National Park. Land Use Policy 2009, 26, 479-492. [CrossRef]

63. Fry, G.L.; Tveit, M.S.; Ode, A.; Velarde, M.D. The ecology of visual landscapes: Exploring the conceptual common ground of visual and ecological landscape indicators. Ecol. Indic. 2009, 9, 933-947. [CrossRef]

64. Gómez Zotano, J.; Riesco Chueca, P. Marco Conceptual y Metodológico Para los Paisajes Españoles: Aplicación a tres Escalas Espaciales; Consejería de Obras Públicas y Vivienda, Centro de Estudios Paisaje y Territorio: Sevilla, Spain, 2010; 467p.

65. Council of Europe. European Landscape Convention; Council of Europe: Florence, Italy, 2000; 7p. 
66. Mazzoni, E. Unidades de paisaje como base para la organización y gestión territorial. Estudios Socioterritoriales 2014, 16 (Suppl. 1). Available online: http:/ / www.scielo.org.ar/scielo.php?script=sci_arttext\&pid=S185343922014000300004\&lng=es\&nrm=iso (accessed on 13 November 2017).

67. Verstappen, H.T. Applied Geomorphology: Geomorphological Surveys for Environments Development; Elsevier: Amsterdam, The Netherlands, 1983; 435p.

68. Van Zuidam, R.A. Aerial Photo-Interpretation in Terrain Analysis and Geomorphologic Mapping; Smiths Publishers: The Hague, The Netherlands, 1986; 350p.

69. Verstappen, H.T.; Zuidam, R.V.; Meijerink, A.M.J.; Nossin, J.J. The ITC System of Geomorphologic Survey: A Basis for the Evaluation of Natural Resources and Hazards; Enschede ITC: Enschede, The Netherlands, 1991; 89p.

70. Minca, C. Humboldt's compromise, or the forgotten geographies of landscape. Prog. Hum. Geogr. 2007, 31, 179-193. [CrossRef]

71. Bolós, M.D. Manual de Ciencia del Paisaje. Teoría, Métodos y Aplicaciones; Colección de Geografía, Masson: Barcelona, Spain, 1992; 273p.

72. Martínez-Graña, A.M.; Goy, J.L.; Zazo, C.; Silva, P.G.; Santos-Francés, F. Configuration and Evolution of the Landscape from the Geomorphological Map in the Natural Parks Batuecas-Quilamas (Central System, SW Salamanca, Spain). Sustainability 2017, 9, 1458. [CrossRef]

73. Brierley, G.; Fryirs, K.; Cullum, C.; Tadaki, M.; Huang, H.Q.; Blue, B. Reading the landscape: Integrating the theory and practice of geomorphology to develop place-based understandings of river systems. Prog. Phys. Geogr. 2013, 37, 601-621. [CrossRef]

74. Phillips, J.D. The perfect landscape. Geomorphology 2007, 84, 159-169. [CrossRef]

75. Bocco, G.; Velázquez, A.; Siebe, C. Using geomorphologic mapping to strengthen natural resource management in developing countries. The case of rural indigenous communities in Michoacan, Mexico. Catena 2005, 60, 239-253. [CrossRef]

76. Isachenko, A.G. Principles of Landscape Science and Physical-Geographic Regionalization; Melbourne University Press: Melbourne, Australia, 1973; 311p.

77. Demek, J. The landscape as a geosystem. Geoforum 1978, 9, 29-34. [CrossRef]

78. Richling, A. Subject of study in complex physical geography (Landscape geography). GeoJournal 1983, 7, 185-187. [CrossRef]

79. Beruchashvili, N.L. Caucasus: Landscapes, Models, Experiments; TGU Publishing House: Tbilisi, Georgia, 1995.

80. Burel, F.; Baudry, J. Landscape Ecology Concepts, Methods and Applications; Science Publishers Inc.: Enfield, NH, USA, 2003; 362p.

81. Frolova, M. Desde el concepto de paisaje a la Teoría de geosistema en la Geografía rusa: Hacia una aproximación geográfica global del medio ambiente? Ería 2006, 70, 225-235.

82. Priego, A.; Bocco, G.; Mendoza, M.; Garrido, A. Propuesta Para la Generación Semiautomática de Unidades de Paisaje; SEMARNAT, INE, CIGA-UNAM: Mexico City, Mexico, 2010; 104p.

83. Franch-Pardo, I.; Priego-Santander, Á.G.; Bollo-Manent, M.; Cancer-Pomar, L.; Bautista-Zúñiga, F. Aplicación de los paisajes físico-geográficos en un sector de la cordillera ibérica: La cuenca del río Martín (Aragón, España). Interciencia 2015, 40, 381-389.

84. Bollo Manent, M.; Hernández Santana, J.R. Paisajes físico-geográficos del noroeste del estado de Chiapas, México. Investig. Geogr. 2006, 66, 7-24.

85. Swanwick, C. Landscape Character Assessment: Guidance for England and Scotland; Technical Report; The Countryside Agency and Scottish Natural Heritage: Gloucestershire, UK, 2002; 104p.

86. Tudor, C. An Approach to Landscape Character Assessment; Core Document 40.20; Natural England: London, UK, 2014; 57p.

87. Warnock, S.; Griffiths, G. Landscape characterisation: The Living Landscapes approach in the UK. Landsc. Res. 2015, 40, 261-278. [CrossRef]

88. Eetvelde, V.V.; Antrop, M. Indicators for assessing changing landscape character of cultural landscapes in Flanders (Belgium). Land Use Policy 2009, 26, 901-910. [CrossRef]

89. Caspersen, O.H. Public participation in strengthening cultural heritage: The role of landscape character assessment in Denmark. Geografisk Tidsskrift Dan. J. Geogr. 2009, 109, 33-45. [CrossRef]

90. Wascher, D. European Landscape Character Areas: Typologies, Cartography and Indicators for the Assessment of Sustainable Landscapes; Research Report; Landscape Europe: Wageningen, The Netherlands, 2005; 160p.

91. Brabyn, L. Classifying landscape character. Landsc. Res. 2009, 34, 299-321. [CrossRef] 
92. Kim, K.-H.; Pauleit, S. Landscape character, biodiversity and land use planning: The case of Kwangju City Region, South Korea. Land Use Policy 2007, 24, 264-274. [CrossRef]

93. Blanco, A.; Gonzales, S.; Ramos, A. Visual landscape classification in the coastal strip of Santander (Spain). Coast. Manag. 1982, 9, 271-297. [CrossRef]

94. Aramburu, M.P.; Escribano, R.; López, R.; Sánchez, P. Cartografía del paisaje de la Comunidad Autónoma de la Rioja; Gobierno de La Rioja-ETSI de Montes de la Universidad Politécnica de Madrid: Logroño, Spain, 2005.

95. Otero, I.; Casermeiro, M.A.; Ezquerra, A.; Esparcia, P. Landscape evaluation: Comparison of evaluation methods in a region of Spain. J. Environ. Manag. 2007, 85, 204-214. [CrossRef] [PubMed]

96. Gobierno de Aragón. Mapas de Paisaje. Available online: http://idearagon.aragon.es/paisaje.jsp (accessed on 14 May 2017).

97. Montoya, R.; Padilla, J.; Stanford, S. Valoración de la calidad y fragilidad visual del paisaje en el Valle de Zapotitlán de las Salinas, Puebla (México). Boletín de la Asociación de Geógrafos Españoles 2003, 35, 123-136.

98. Franch-Pardo, I.; Cancer-Pomar, L. El componente visual en la cartografía del paisaje. Aptitud paisajística para la protección en la cuenca del río Chiquito (Morelia, Michoacán). Investig. Geogr. 2017, 93, 42-60. [CrossRef]

99. Cancer-Pomar, L. Ecogeografía de los Paisajes del Alto Gállego; Consejo de Protección de la Naturaleza de Aragón: Zaragoza, Spain, 1995; 314p.

100. Franch-Pardo, I.; Cancer-Pomar, L.; Napoletano, B.M. Visibility analysis and landscape evaluation in Martin River Cultural Park (Aragon, Spain) integrating biophysical and visual units. J. Maps 2017, 13, 415-424. [CrossRef]

101. López-Santiago, C. Lo Universal y lo Cultural en la Estética del Paisaje. Experimento Transcultural de Percepción del Paisaje. Ph.D. Thesis, Universidad Autónoma de Madrid, Madrid, Spain, 10 January 1994.

102. González Bernáldez, F. Invitación a la Ecología Humana. La Adaptación Afectiva al Entorno, 1st ed.; Tecnos: Madrid, Spain, 1985; 159p.

103. González Bernáldez, F. El paisaje natural. In Figura con Paisajes. Homenaje a Fernando González Bernáldez, 1st ed.; Montes del Olmo, C., Levassoir Riche, C., de Otaola, S.C., Cuenca Fernández, A., Eds.; González Bernáldez: Madrid, Spain, 2002; pp. 132-145.

104. Appleton, J. The Experience of Landscape, 1st ed.; John Wiley \& Sons Ltd.: Chichester, UK, 1975; 296p.

105. Gibson, J.J. The Ecological Approach to Visual Perception, 1st ed.; H. Mifflin Co.: Boston, MA, USA, 1979; 305p.

106. Kaplan, S.; Kaplan, R. Cognition and Environment, 1st ed.; Praeger Ed.: New York, NY, USA, 1982.

107. Barrasa García, S. Valoración de la calidad estética de los paisajes de La Habana (Cuba) con métodos de participación social. Estudios Geográficos 2013, 274, 45-66. [CrossRef]

108. López-Santiago, C.; Oteros-Rozas, E.; Martín-López, B.; Plieninger, T.; González-Martín, E.; González, J.A. Using visual stimuli to explore the social perceptions of ecosystem services in cultural landscapes: The case of transhumance in Mediterranean Spain. Ecol. Soc. 2014, 19, 27. [CrossRef]

109. McHarg, I. Proyectar con la Naturaleza; Gustavo Gili: Barcelona, Spain, 2000; 216p.

110. Antrop, M.; Van Eervelde, V. Holistic aspect of suburban landscape. Visual image interpretation and landscape metrics. Landsc. Urban Plan. 2000, 50, 43-58. [CrossRef]

111. Hedding, D.W. Spatial inventory of landforms in the recently exposed central highland of sub-Antarctic Marion Island. S. Afr. Geogr. J. 2008, 90, 11-21. [CrossRef]

112. Souza Filho, P.W.M.; Paradella, W.R. Recognition of the main geobotanical features along the Bragança mangrove coast (Brazilian Amazon Region) from Landsat TM and RADARSAT-1 data. Wetl. Ecol. Manag. 2002, 10, 121-130. [CrossRef]

113. Bocco, G.; Napoletano, B.M. The prospects of terrace agriculture as an adaptation to climate change in Latin America. Geogr. Compass 2017, in press. [CrossRef]

114. Schellnhuber, H.J.; Crutzen, P.J.; Clark, W.C.; Hunt, J. Earth system analysis for sustainability. Environ. Sci. Policy Sustain. Dev. 2005, 47, 10-25. [CrossRef]

115. Mata Olmo, R. El paisaje, patrimonio y recurso para el desarrollo territorial sostenible. Conocimiento y acción pública. Arbor 2008, 184, 155-172.

116. Conrad, E.; Cassar, L.F.; Jones, M.; Eiter, S.; Cová, Z.I.; Barankova, Z.; Christie, M.; Fazey, I. Rhetoric and Reporting of Public Participation in Landscape Policy. J. Environ. Policy Plan. 2011, 13, 23-47. [CrossRef]

117. Lawton, J.H. Ecology, politics and policy. J. Appl. Ecol. 2007, 44, 465-474. [CrossRef] 
118. Butler, A.; Berglund, U. Landscape character assessment as an approach to understanding public interests within the European Landscape Convention. Landsc. Res. 2014, 39, 219-236. [CrossRef]

119. James, P.; Gittins, J.W. Local landscape character assessment: An evaluation of community-led schemes in Cheshire. Landsc. Res. 2007, 32, 423-442. [CrossRef]

120. Ode, A.; Tveit, M.S.; Fry, G. Capturing landscape visual character using indicators: Touching base with landscape aesthetic theory. Landsc. Res. 2008, 33, 89-117. [CrossRef]

121. Butler, A.; Åkerskog, A. Awareness-raising of landscape in practice. An analysis of Landscape Character Assessments in England. Land Use Policy 2014, 36, 441-449. [CrossRef]

122. Lee, K.C.; Son, Y.H. Exploring Landscape Perceptions of Bukhansan National Park According to the Degree of Visitors' Experience. Sustainability 2017, 9, 1306. [CrossRef]

123. Cherem, G.J.; Driver, B.L. Visitor employed photography: A technique to measure common perceptions of natural environments. J. Leis. Res. 1983, 15, 65-83.

124. De Lucio Fernández, J.V. Paisaje y ecología del paisaje. In Figura con Paisajes. Homenaje a Fernando González Bernáldez, 1st ed.; del Olmo, C.M., Levassoir Riche, C., Casado de Otaola, S., Cuenca Fernández, A., Eds.; González Bernáldez: Madrid, Spain, 2002; pp. 126-131.

125. Dramstad, W.E.; Sundli, M.; Fjelltad, W.J.; Fry, G.L.A. Relationships between visual landscape preferences and map-based indicators of landscape structure. Landsc. Urban Plan. 2006, 78, 465-474. [CrossRef]

126. Farina, A.; Scozzafava, S.; Napoletano, B. Therapeutic landscapes: Paradigms and applications. J. Mediterr. Ecol. 2007, 8, 9-16.

127. Robbins, P. Lawn People: How Grasses, Weeds, and Chemicals Make Us Who We Are; Temple University Press: Philadelphia, PA, USA, 2007; 208p.

128. Garibray Orozco, C.; Boni, A.; Panico, F.; Urquijo, P.; Klooster, D. Unequal Partners, Unequal Exchange: Goldcorp, the Mexican State, and Campesino dispossession at the Peñasquito goldmine. J. Latin Am. Geogr. 2011, 10, 153-171. [CrossRef]

129. Bocco, G. Remoteness and remote places. A geographic perspective. Geoforum 2016, 77, 178-181. [CrossRef]

130. Garibay Orozco, C.; Balzaretti Camacho, A. Goldcorp y la reciprocidad negativa en el paisaje minero de Mezcala, Guerrero. Desacatos 2009, 30, 91-110.

131. Scott, A. Beyond the conventional: Meeting the challenges of landscape governance within the European Landscape Convention? J. Environ. Man. 2011, 92, 2754-2762. [CrossRef] [PubMed]

132. Smil, V. The Earth's Biosphere: Evolution, Dynamics, and Change; The MIT Press: Cambridge, MA, USA, 2002; 346p.

133. Scott, J.C. Domination and the Arts of Resistance: Hidden Transcripts; Yale University Press: New Haven, CT, USA, 1999; 269p. 